\title{
Review of Cretaceous dipnoans from Argentina (Sarcopterygii: Dipnoi) with descriptions of new species
}

\author{
Sebastián APESTEGUÍA ${ }^{1,2,3}$, Federico L. AGNOLIN ${ }^{2}$ \& Kerin CLAESON ${ }^{4}$ \\ ${ }^{1}$ Museo Patagónico de Ciencias Naturales, Av. Roca 1250, (8334) General Roca, Río Negro, Argentina. \\ ${ }^{2}$ Museo Argentino de Ciencias Naturales 'B. Rivadavia', Av. Ángel Gallardo 470, (1405) Buenos Aires, \\ Argentina. ${ }^{3}$ Área de Paleontología, Fundación de Historia Natural 'Félix de Azara'. CEBBAD - \\ Universidad Maimónides. V. Virasoro 732, (1405) Buenos Aires, Argentina. ${ }^{4}$ Graduate Program in \\ Organismic and Evolutionary Biology, University of Massachusetts, 611 North Pleasant St., Amherst, MA \\ 01003-9297, U.S.A. \\ E-mails: paleoninja@yahoo.com.ar, fedeagnolin@yahoo.com.ar, kclaeson@bio.umass.edu.
}

\begin{abstract}
In this paper we review the fossil ceratodontiform record from the Cretaceous of Argentina. We report the oldest dipnoan record from Argentina, coming from the Cenomanian of Northwestern Patagonia, Río Negro province. The species «tCeratodus» iheringi is reassigned. Additionally, four new species are described. Ceratodontiforms were considered extinct in Laurasia after the mid-Cretaceous, with a brief «reappearance» during the Maastrichtian before their definitive extinction from South America and most of the world by K/P bound-ary. Based on our phylogenetic analysis, using characters derived primarily from tooth plates, we propose that the genus †Metaceratodus is more closely related to Neoceratodus than either is to TCeratodus or †Ptychoceratodus, supporting prior hypotheses. In two most parsimonious trees, the two new genera here described are basal, being one of them sister taxa to Ceratodontoidea nov. and the other unresolved with respect to Protopterus.
\end{abstract}

Key words: Paleontology, Cretaceous, dipnoans, Patagonia, Argentina.

Dipnoi (lungfishes) are a monophyletic group of sarcopterygians, restricted today to the Southern Hemisphere (Kemp, 1997). They are represented by two living orders: Lepidosireniformes (Africa and South America) and Ceratodontiformes (Australia). During the Paleozoic and Mesozoic, however, dipnoans had a global distribution. In South America, the record of ceratodontiforms spans the Late Cenomanian (Apesteguía et al ., 2001) through the Paleocene (Schultze, 1991). In Argentina, ceratodontiforms are perhaps the most abundant fossils found in formations representing the 'Lacustrine Senonian', the first stages of the Campanian-Maastrichtian sea transgression (e.g. Los Alamitos, La Colonia, Paso del Sapo Formations; Pascual \& Bondesio, 1976).

Since Ameghino (1899) described the tooth plate of 'TCeratodus' iheringi, from the Mata Amarilla Formation (see F. Ameghino, 1906 and C. Ameghino, 1916), their systematic position remained uncertain (Martin, 1981, 1982). Despite the fact that in Argentina, localities yield an abundance of fossil dipnoan tooth plates (Fig. 1a), the diver-sity and stratigraphic distribution of these speci-mens has not been reported throughly. This is also true for the remaining countries of South America, where the Cretaceous record of dipnoans is sparse and strongly biased (Souza Cunha \& Ferreira, 1980; Gayet \& Brito, 1989; Schultze, 1991).
Few phylogenetic reviews have been conducted on fossil dipnoans from Argentina due to the lack of morphological data beyond tooth plates. Martin (1982: p. 56) reviewed the ceratodontiform record of Argentina as part of an analysis of postpaleozoic lungfishes, and from the Campanian-Maastrichtian of the Los Alamitos Formation. Cione (1987) described 'TCeratodus' iheringi. Both Martin (1982) and Cione (1987) related '†Ceratodus' iheringi with tPtychoceratodus madagascarensis. Kemp (1997) reassigned 'TCeratodus' iheringi to TMetaceratodus, whereas Schultze (1991) (see also Kirkland, 1987) proposed that they were related to those coming from the Upper Jurassic of North America and the Upper Cretaceous of Madagascar.

In this paper we conduct a new study of Argentinian ceratodontiform systematics, promp-ted by the discovery of well-preserved ceratodontiform tooth plates from several Cretaceous beds of Patagonia. We also address the value of tooth plates in systematic analyses and review the temporal distribution of South American Ceratodontiformes.

\section{METHODS}

Our character matrix includes characters adapted from Martin (1982), Martin et al. (1999), Kirkland (1988), and Kemp (1998), as well as new characters discovered and scored for this study 
A

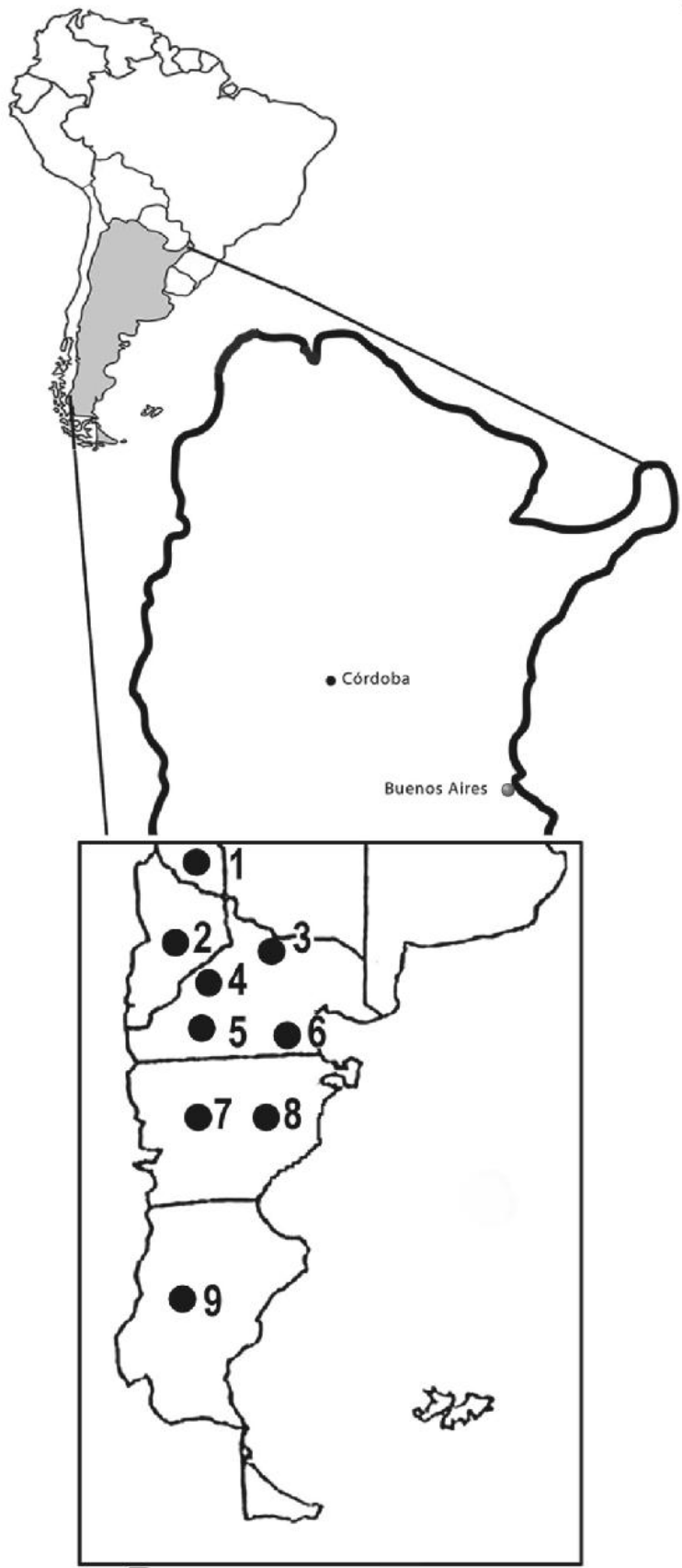

B

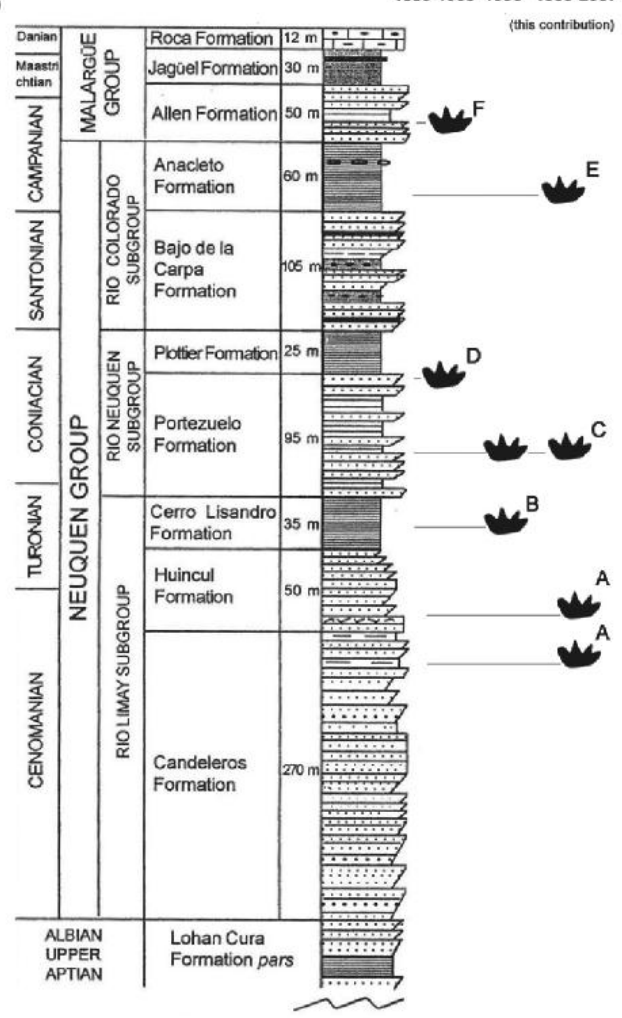

C

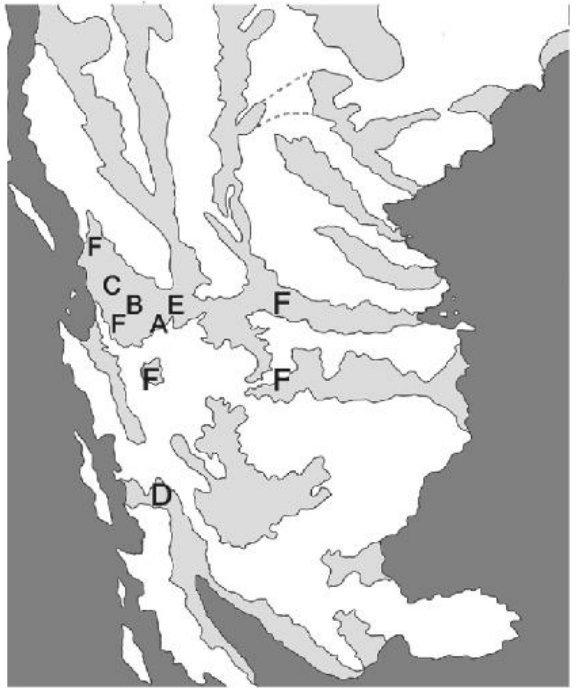

Fig. 1. A. Map of South America showing fossiliferous localities. Patagonian region into the box shows the localities that provided dipnoan remains, identified with the following numbers: 1, Ranquil Có; 2, Sierra del Portezuelo; 3 , Paso Córdova; 4, La Buitrera; 5, Ingeniero Jacobacci; 6, Los Alamitos; 7, Paso del Sapo; 8, La Colonia; 9, Mata Amarilla. B, Stratigraphic column showing the aproximate levels of ceratodontiform findings and the bearing units in the studied region. Shaded tooth plates do not represent any special taxon. D and F include also findings outside the Neuquén Group areal distribution. The inclusion in the stratigraphic column is only for reference. C, Paleogeographic reconstruction of the southernmost tip of South America during Santonian to Early Campanian times, before the Kawas Sea ingression (modified from Apesteguía, 2002) . Lettering repre-sent the dipnoan findings related to the bearing stratigraphic level; aulacogens are corrected; valley shapes and coastal details are not rigorous. 
(see Appendix 1). Parsimony analysis was performed on the matrix of 9 taxa and 28 characters (see Appendix 2). Ceratodontiform tooth plates examined are primarily Jurassic and postJurassic, with one exception, the Triassic †ceratodontid TPtychoceratodus (Jaeckel 1926) due to its relevance to Gondwanan taxa. The matrix was analyzed with NONA (Goloboff, 1993). The analysis resulted in two most parsi-monious trees, the strict consensus of which re-sulted in a single tree (Fig. 6). (Tree description using NONA: 70 length, $\mathrm{Cl}$ 67, and RI 55.

Abbreviations and terminology. MACN, Museo Argentino de Ciencias Naturales «Bernardino Rivadavia», Buenos Aires; MLP, Museo de Ciencias Naturales de La Plata, La Plata; MEF, Museo Paleontológico «Egidio Feruglio», Trelew; PVPH, Museo Provincial «Carmen Funes», Plaza Huincul; MPCA, Museo Provincial «Carlos Ameghino», Cipolletti; MPCN, Museo Patagónico de Ciencias Naturales, General Roca, Río Negro; ROM, Royal Ontario Museum, Collection of Ver-tebrate Fossils, Toronto, Canada. Kemp (1998) is followed for cranial bone terminology.

\section{SYSTEMATIC PALAEONTOLOGY}

\author{
Dipnoi Müller, 1845 \\ Ceratodontiformes Berg, 1940
}

\section{†Chaoceratodus gen. nov.}

Type species. †Chaoceratodus portezuelensis. Diagnosis. Small sized (see Table I) . Upper tooth plates with four ridge crests, being the sec-ond the smallest. A non- sculptured tubercle is present on the labial side of each ridge crest and midway up the first.

Etymology. Chao: from mapuche 'father'.

tChaoceratodus portezuelensis, nov. sp. (Fig. 2A)

Diagnosis. As for the genus.

Etymology. From Sierra del Portezuelo, the place of discovery.

Holotype. MCF-PVPH-373, left upper tooth plate. Horizon and locality. This specimen was found in

Portezuelo Formation, Sierra del Portezuelo, Neuquén Province (Turonian; see Novas, 1997). Description. The tooth plate is subtriangular, with four robust and short ridge crests. Clefts between the ridges are wide and shallow. The labial profile of the crests is not steep and ends in a single last crest. The first crest is long and broad, without a marked slope. The crests are relatively straight and radiating. The fourth crest is very large when compared with the second and the third. Occlusal pits are nearly absent on the occlusal surface. There are large tubercles in the labial edge of the crests except in the first where the tubercle is located toward the central region.

tChaoceratodus represents a basal genus when considering it in reference to Ceratodontiformes. It retains several plesiomorphic traits, such as a straight lingual margin of the tooth plate. The occlusal surface is uniformly and completely punctuated and shows a very short first ridge crest.

Also from the Portezuelo Formation at Sie-rra del Portezuelo, a partial lower tooth plate (PVPH 373; Fig. 2B) of a large indeterminate dipnoan was recovered. This plate represents a pathological specimen because it shows two abnormal bumps on its crushing surface.

\section{Unnamed Node 1}

Definition. Ceratodontiform dipnoans more closely related to †Ameghinoceratodus and Ceratodontoidea nov. than to + Chaoceratodus.

Diagnosis. ABC angle less than $110^{\circ}$; upper tooth plates with five ridge crests.

comments. This node includes all postJurassic ceratodontiform taxa except the genus tChaoceratodus.

\section{†Ameghinoceratodus gen. nov.}

Type species. †Ameghinoceratodus iheringi (Ameghino, 1899).

Diagnosis. Small sized (see Table I). All the ridge crests of tooth plates are acute and gracile. Upper tooth plates have five ridge crests and the lower have four. The first upper ridge crest is curved and the others are nearly straight. The last two upper ridge crests are rather similar in size and oriented strongly backwards.

Etymology. Ameghino, for Florentino, Carlos and Juan, the formidable team of brothers that strenghtened the Paleontological bases in Argentina.

\section{†Ameghinoceratodus iheringi (Ameghino, 1899) nov. comb.(Fig. $2 \mathrm{C}-\mathrm{E}$ )}

Diagnosis. As for the genus.Holotype. MLP 21-967, left upper tooth plate (Fig. 2C).

Referred material. Materials recently collected in the Mata Amarilla Formation (Goin et al., 2002, and pers. obs., Fig. 2E); MPCA 401, left lower tooth plate, Huincul Formation (see Apesteguía et al. 2001; Fig. 2D); MACN PV RN157C, right lower tooth plate, Los Alamitos Formation (see Bonaparte et al. 1984), and 
Table 1. Measurements (in $\mathrm{mm}$ ) of fossil tooth plates.

\begin{tabular}{lcccc}
\hline & & & \multicolumn{2}{c}{ Height } \\
\cline { 5 - 5 } Taxon Studied & Specimen & Total Length & 10 $^{\circ}$ ridge crest & $2^{\circ}$ ridge crest \\
\hline TChaoceratodus portezuelensis & MCF-PVPH-373 & 12.8 & 8.3 & 4.5 \\
TPtychoceratodus cionei & MACN-RN 157B & - & - & 18.8 \\
TPtychoceratodus wichmanni & MACN-RN 157A & - & - & 14.1 \\
TAmeghinoceratodus iheringi & MPCA 401 & 13.5 & - & 8.5 \\
TCeratodus argentinus & MPCA 402 & - & - & 21 \\
tCeratodus kaopen & MPCN-PV 1-1 & 31 & 21.6 & 16 \\
\hline
\end{tabular}

Portezuelo Formation at Cerros Colorados (south) (MCF-PVPH-572, Fig. 5g).

Horizon and locality. The type specimen comes from the Mata Amarilla Formation (Coniacian), Santa Cruz Province.

Description. Upper tooth plates with five ridge crests, whereas the lower have only four. Each crest is narrow and slender. Clefts corresponding to ridges are narrow and deep. The labial profile of the crests is steep and ends in a single vertical ridge. The first crest is relatively long and thin, with a marked angle on the labial side. All crests can be curved, though the degree of curvature may vary. The fourth crest is usually long (when compared with other ceratodontiform genera, e.g. TCeratodus). The lingual profile could be straight or slightly concave. Occlusal pits are nearly absent.

Comments. TAmeghinoceratodus iheringi, consigned by Ameghino as Ceratodus iheringi, has an exceptionally wide biochron that extends from Cenomanian to Maastrichtian times. We did not include tAmeghinoceratodus iheringi nov. within the genera TMetaceratodus or TPtychoceratodus (contra Kemp, 1997; Martin, 1982) because it lacks several derived characters shared by the aforementioned genera, such as: medial edge of lower tooth plates not bent and lingual margin of tooth plates straight or concave (instead of convex). The material MCF- PVPH-572 from the Portezuelo Formation (Fig. $5 \mathrm{~g}$ ) can be assigned to this genus because of the strongly backwards oriented last two upper ridge crests, that are also similar in size each other.

\section{Ceratodontoidea nov.}

Type species. †Ceratodus latissimus Agassiz, 1838 (Fig. 2j)

Definition. The node that includes Neoceratodontidae, †Ceratodontidae (†Ptychoceratodontinae + †Ceratodontinae), their common ancestor and all of its descendants.
Diagnosis. The medial edge of the lower tooth plate is bent; the lingual margin of the upper and lower tooth plates is convex; anteroposterior length of tooth plates more than $2,5 \mathrm{~cm}$; upper plates with six ridge crests.

\section{†Ceratodontidae Gill, 1872}

Type species. †Ceratodus latissimus Agassiz, 1838.

Modified definition . Ceratodontiform dipnoans more closely related to $+C e r a t o d u s ~ s t u r i i$ and †Ptychoceratodus serratus than to Neoceratodus forsterii.

Diagnosis. JLM descendant process absent; posterior calvarium formed by $\mathrm{YZ}, \mathrm{JLM}, \mathrm{I}, \mathrm{ABC}$; short ridge crests on tooth plates; upper symphysis oblong, lower symphysis linear; Four to five ridge crests on lower tooth plates.

Remarks. †Ceratodontidae (sensu Gill, 1872) refers to the type species TCeratodus latissimus (Agassiz, 1838), and for diagnosis of the subfamily †Ceratodontinae. Taking into account the almost identical morphology of tCeratodus sturii respect to C. latissimus (Fig. 2j) and the presence of highly diagnostic cranial materials, we have used tCeratodus sturii (Teller, 1891) as the represen-tative of the genus in our phylogenetic analysis (Fig. 6).

\section{†Ceratodontinae (Gill, 1872) nov. comb.} 1838.

Type species. †Ceratodus latissimus Agassiz,

Modified definition. Ceratodontiform dipnoans more closely related to tCeratodus sturii than to TPtychoceratodus serratus. The taxon was evaluated only for species of Ceratodus but fur-ther phylogenetic analyses could show other gen-era as included here.

Diagnosis. Tooth plates with low and wide ridge crests. 

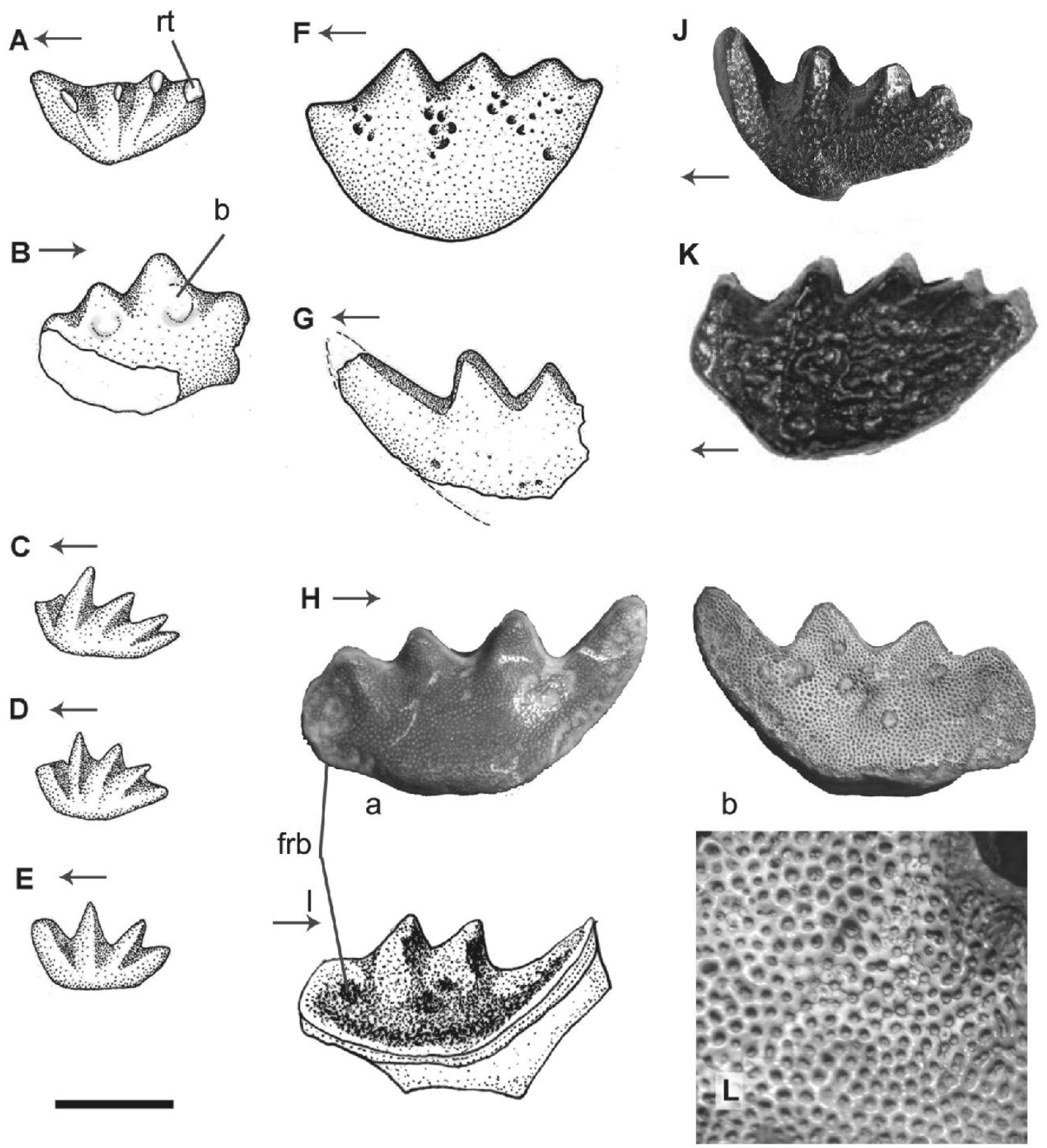

Fig. 2. A, TChaoceratodus portezuelensis (MCF-PVPH- 373, holotype) left upper tooth plate in occlusal view; B, Ceratodontiformes indet. (MCF-PVPH-374) left lower tooth plate in occlusal view; C-E, †Ameghinoceratodus iheringi, all in occlusal view; C, (MLP-21-967, holotype) left upper tooth plate; D , (MPCA-401) left upper tooth plate; $\mathbf{E}$, right lower tooth plate; $\mathbf{F}$, †Ceratodus argentinus (MPCA-402, holotype) left upper tooth plate in occlu-sal view; G, †Cf. Ceratodus kaopen (MPCA-403) fragmentary left lower tooth plate in occlusal view; $\mathbf{H}$, tCeratodus kaopen (MPCN-PV 1- 1, holotype) left lower tooth plate in a, occlusal and b, ventral views; I, †Ceratodus kaopen (MLP-94$\mathrm{XI}-1$-1), left lower tooth plate in occlusal view. J, tCeratodus latissimus; right lower tooth plate in occlusal view (BMNH P 39089, Triassic of England); K, †Ceratodus humei; right lower tooth plate in occlusal view (ROM 47628); L, †Ceratodus kaopen a, detail of the pitted ventral surface in the lower tooth plate MPCN-PV 1- 2. Scale bar equals $1 \mathrm{~cm}$. for all except I (1,5 cm.). Fig. J and K modified from Kemp (2001) and Churcher \& de Iuliis (2001) respectively. Arrows indicate rostral direction. Abbreviatures: b, bump; frb, fourth ridge basin; rt, ridge tubercle. 


\section{tCeratodus argentinus sp. nov.(Fig. 2 F)}

Diagnosis. Mid-sized (see Table I). Upper tooth plates with five ridge crests. The third crest is larger than the fourth. The plate becomes thinner at the back.

Etymology. From Argentina, the country in which the new species was found.

Holotype. MPCA 402, left upper tooth plate that lacks most of its first crest.

Horizon and locality. Candeleros Formation (Cenomanian). La Buitrera (Río Negro Prov.). Description. The tooth plate is low, subtriangular, with four robust, short crests. A fifth crest is present though reduced in size. Clefts between the ridges are wide and shallow. The labial profile of the crests is not steep and ends in a heel. The crests are subequal in size and morphology, nearly straight and radiating. Occlusal pits are sparse and are distributed mainly between the crests.

tCeratodus argentinus is similar to $\dagger C$. concinnus (sensu Martin, 1982) in having a reduced fifth ridge crest and a tall third crest ridge. It is similar to $+C$. fossanovum (Kirkland, 1988) of the Upper Jurassic Morrison Formation (Uni-ted States) in having a lingually expanded mar-gin forming a flat crushing surface.

\section{†Ceratodus kaopen sp. nov.} (Fig. $2 \mathrm{H}$ )

Diagnosis. Mid-sized (see Table I). Upper tooth plates with four crests. The anterolingual region forms a tall ridge. The second and third crests are tall and bent lingually. The fourth crest is very low and squared.

Etymology. From kaopen, meaning «reddish» in the northern Tehuelchean (Patagonian natives) language, because of its finding in sediments of the Río Colorado («Red River») Sub-group.

Holotype. MPCN-PV 1-1, complete left lower tooth plate.

Referred material. MLP 94-XI- 1-1, complete left lower tooth plate, MPCN -PV $1-2$, anterior fragment with two ridges of a right lower tooth plate, MPCN-PV 1-3, anterior fragment with two ridges of a right upper tooth plate with cranial bone attached.

Horizon and locality. Bajo de la Carpa Formation (Santonian). Paso Córdova (Río Negro Province).

Description. The tooth plate is subtriangular, with four robust and short crests. Clefts between the ridges are wide and shallow. The labial profile of the crests is not steep and ends in a single last crest. The crests are nearly straight. The first crest is long and broad, more pronounced than the adjacent two crests, without a marked slope and only slightly bent, preserving a rostral instead of a lateral direction. The $A B C$ angle is pronounced as in Ameghino-ceratodus rather than gentle as in Ptycho-ceratodus. The fourth crest is very wide, square and its occlusal surface is nearly flat. Caudally and lingually from the fourth crest, there is a marked depression for an upper crest. Occlusal pits are nearly absent in the occlusal surface. The second and third crests are dorsally convex.

†Ceratodus kaopen is similar to $+C$. frazieri, (Ostrom, 1970) from the Jurassic Morrison Formation (United States) in having a large first ridge crest, and in showing an anteroposteriorly expanded fourth ridge crest forming a flat crushing surface (Kirkland, 1987).

\section{Other ceratodontids}

By 1995 to 1999, Rodolfo Coria's parties to the Bayo Mesa, Cerros Colorados and Portezuelo Hills collected abundant material of cerato-dontiform dipnoans. They were briefly mentioned in an abstract (Coria et al., 1996) and kindly of-fered to be studied here. These specimens are important as they are stratigraphically far from any marine transgression and they clearly sup-port the abundance and big size of dipnoans in fluvial and lacustrine fully freshwater environ-ments.

Recorded ceratodontids include the material MCF-PVPH-426,432,500 (Figs. 4a, c, e), belonging to the genus Ceratodus itself, considering their rounded crests, with a low occlusal surface. This material comes from the Cerro Lisandro Forma-tion at the Cerro Bayo Mesa $(426,432)$ and the Cerros Colorados localities.

\section{†Ptychoceratodontinae (Martin, 1982) nov. comb.}

†Ptychoceratodus Jaeckel, 1926

Type species. †Ptychoceratodus serratus (Agassiz 1838).

Modified definition. Ceratodontiform dipnoans more closely related to †Ptychoceratodus serratus than to †Ceratodus sturii. The taxon was evaluated only for species of Ptychoceratodus but further phylogenetic analyses could show other genera as included here.

Modified diagnosis. Calvarian bones distribution: three bones in medial and mediolateral se- 
ries; posterior calvarium formed by I, AB; calvarium emarginated only on its posterior edge; occlusal perforations distributed mainly among the ridge crests; four acute ridge crests in the lower tooth plates; fourth ridge crest on lower tooth plate present and well developed.

\section{tPtychoceratodus cionei sp. nov.}

(Fig. 3 A, B)

Diagnosis. Mid-sized (see Table I). Upper tooth plate with four crests that widens towards the labial edge. The 2 nd ridge crest is the largest.

Etymology. After Prof. Dr. Alberto Cione, Argentinian paleoichthiologist.

Holotype. MACN PV RN157B, left lower tooth plate.

Referred material. MACN PV RN157 pars; Wichmann (1924; Plate VII, fig. 5).

Horizon and locality. Los Alamitos Ranch (Río Negro Province). Los Alamitos Formation (Campanian-Maastrichtian; see Bonaparte et al. 1984).

Description. The tooth plate is subtriangular, with four robust and acute crests. Clefts between the ridges are wide and deep. The labial profile of the crests is steep and ends in a single last crest. The first crest shows a marked slope. The crests are nearly straight and radiating. Occlu-sal pits are present and are well developed over the crests. The crests are dorsoventrally ex-panded in its labial side.

+ Ptychoceratodus cionei is similar to $T P$. madagascariensis (=Ferganaceratodus of Mar-tin et al., 1999) in having an obtuse lingual angle and smooth ridge crests not directed anteriorly (Martin, 1982). It shares with $T P$. wichmanni (see description) only four ridge crests (instead of five) on upper tooth plates. Additionally, $P$. cionei differs from $P$. wichmanni in being more robust and in having the cleft between the ridge crests shallower.

\section{tPtychoceratodus wichmanni sp. nov.(Fig. 3 C - D)}

Diagnosis. Mid -sized (see Table I). Upper and lower tooth plates with four ridge crests. Lower tooth plates have sharp long and thin ridge crests. The first is very elongate, and the fourth is posteriorly directed.

Etymology. After Dr. Ricardo Wichmann, the early twentieth century geologist who made important contributions to the study of the referred area.

Holotype. MACN PV RN157A, left upper tooth plate (Fig. 3C).
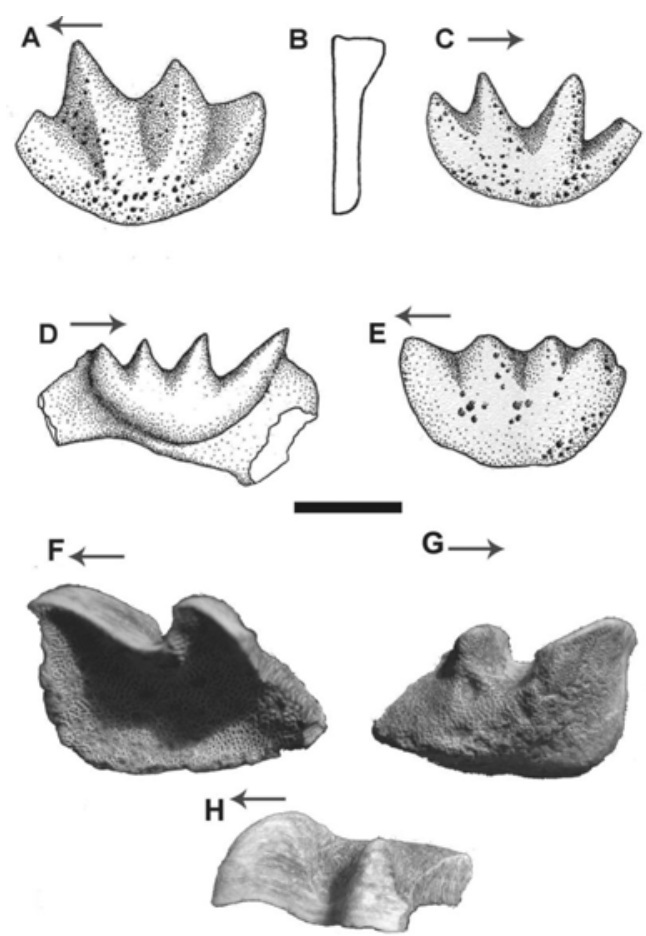

Fig. 3. A- B tPtychoceratodus cionei (MACN-RN- 157b, holotype) right upper tooth plate in (A) occlusal view,

(B) cross section; C-D, +Ptychoceratodus wichmanni in occlusal view; C, (MACN-RN 157a, holotype) left upper tooth plate; $\mathbf{D}$, right upper tooth plate (referred specimen, modified from Cione, 1987); E, tMetaceratodus wollastoni, left upper tooth plate in occlusal view (referred specimen, modified from Pascual and Bondesio, 1976); F-H, ?Lepidosirenidae (MPCN-PV 1-6), fragmentary plate in ventral $(F)$, occlusal $(G)$, and labial $(H)$ views, preserving only two ridges. Scale bar equals 1 $\mathrm{cm}$. Arrows indicate rostral direction.

Referred material. Wichmann (1924: Plate VII, fig. 6; 1927: fig. 1, 3; 12) Cione, (1987: fig. 1.N.) and González Riga (1999, fig. E.).

Horizon and locality. The holotype and the referred material come from the Los Alamitos Formation (Campanian-Maastrichtian). Estancia Los Alamitos (Río Negro Province).

Additional material. Several isolated tooth plates referred to the same species as that from the Los Alamitos Formation come from equivalent units at Arroyo Yaminué, Trapal-có and several localities where the Allen Formation is exposed (Río Negro Province; Wichmann, 1927). Additional material comes from southern Mendoza localities (e.g. Ranquil-Co; González Riga, 1999) of the Loncoche Formation (also equivalent to the Los Alamitos Formation).

Description. Tooth plates with narrow and acute crests. Clefts between the ridges are narrow and deep. The labial profile of the crests is not steep. 
A
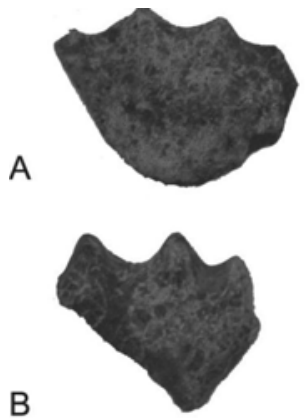

B

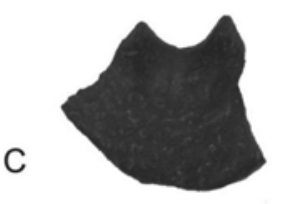

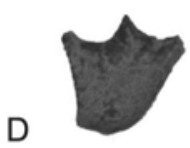

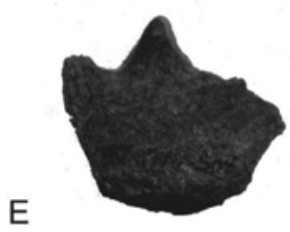

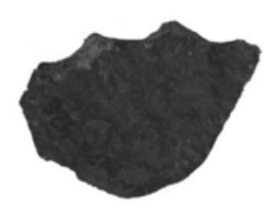
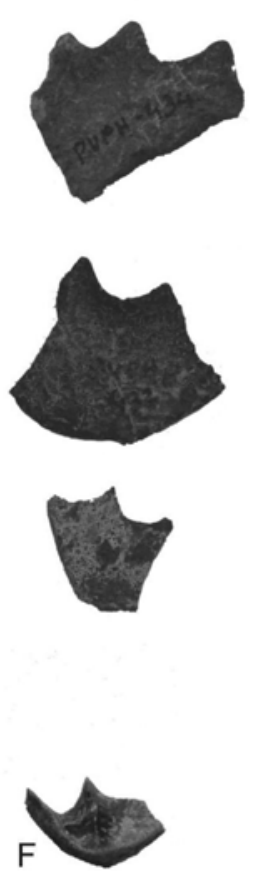

$\mathrm{H}$
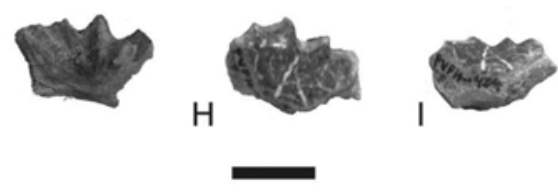

Fig. 4. A (MCF-PVPH-426), C (MCF-PVPH-432), E (MCF-PVPH-500), Ceratodontidae indet., lower tooth plates; F (MCF-PVPH-506, upper), H (MCF-PVPH-424, lower), I (PVPH- 424, lower, different angle), Ptychoceratodontidae indet., tooth plates; G (MCF-PVPH572, lower), Ameghinoceratodus sp.; $\mathbf{B}$ and $\mathbf{D}$, unnumbered material from the Cerro Lisandro Formation at Cerro Bayo Mesa.

The first crest is relatively long and thin, with a marked slope. The crests are nearly straight and radiating, and the fourth crest is the shortest. Occlusal pits are well developed and are mainly distributed over the crests. Occlusal surface is flat.

As was indicated earlier, $t P$. wichmanni is similar to $T P$. cionei, from which it differs, among other characters (see specific diagnoses) in having more gracile tooth plates and deeper and narrower clefts between ridge crests. $T P$. wichmanni also shares feathers with $+P$. madagascariensis as was implied by Martin (1982) and Cione (1987; see above).
The plates of $T P$. wichmanni were originally referred by Martin (1982) and Cione (1987) to the species "†Ceratodus» iheringi (†Ameghino ceratodus iheringi herein). $† P$. wichmanni, how-ever, is larger than $+A$. iheringi (see Table 1 ) and has deep and abundant occlusal pits and broad, low and acute ridge crests absent in †Ameghi-noceratodus. Additionally $T P$. wichmanni shows a strongly convex lingual margin of the tooth plates. We would also like to point out that $T P$. wichmanni is the most common dipnoan species present in Campanian Maastrichtian beds from Argentina.

\section{Other ptychoceratodontids}

Recorded ptychoceratodontids include the material MCF-PVPH- 424, 506 (Figs. 4d, f, h, i), considering the acute crests and well developed crunching surface. This material comes from the Cerro Lisandro Formation at the Cerros Colorados south (506) and the Portezuelo Formation at the homonimous locality (424).

The material on Fig. 5 share very fragile and acute crests, probably a same Ptychoceratodus species, which is very comparable to tPtychoceratodus madagascariensis (=Ferganaceratodus of Martin et al., 1999).

Neoceratodontidae Miles, 1977 1870).

Type species. Neoceratodus forsteri (Krefft,

Modified definition. Ceratodontiform dipnoans more closely related to Neoceratodus forsteri than to †Ceratodus sturii (Fig. 6).

Modified diagnosis. Double prearticular sulcus; seven upper tooth ridge crests; more than six lower tooth ridge crests (reversed in $\mathrm{M}$. wollastoni, but present in other †Metaceratodus species, such as M. bonei).

†Metaceratodus wollastoni (Chapman, 1914) (Fig. $3 \mathrm{E}$ )

\section{Type species. †Metaceratodus wollastoni}

(Chapman, 1914).

Referred material. Pascual \& Bondesio (1976; Plate I, fig. 9); Wichmann (1924; Plate VII, fig. 4).

Horizon and locality. Ingeriero Jacobacci (Río Negro province). Coli Toro Formation (Campanian-Maastrichtian; see Pascual \& Bondesio, 1976).

Comments. The genus tMetaceratodus is considered here to be the sister group of TMioceratodus + Neoceratodus (Neoceratodontidae), not of †Ceratodontidae (Schultze, 1992; contra Kemp, 


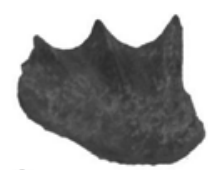

A

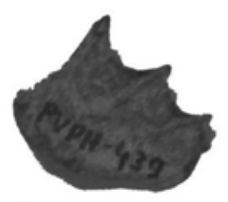

B
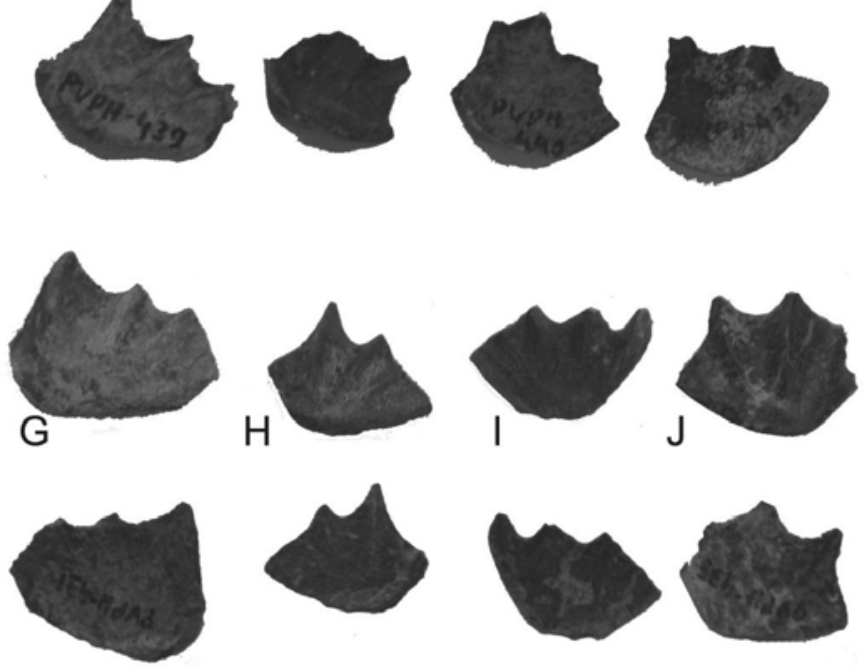
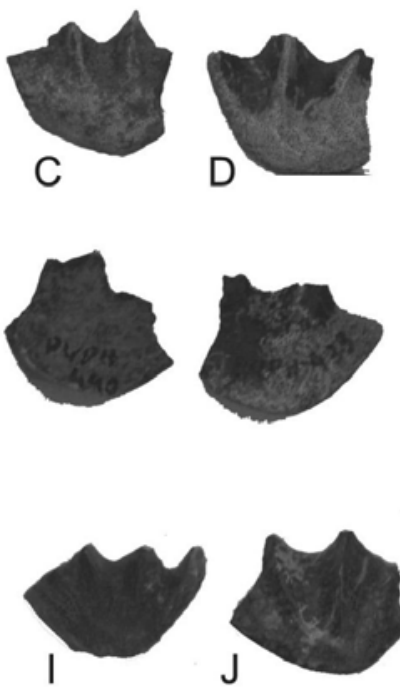

C
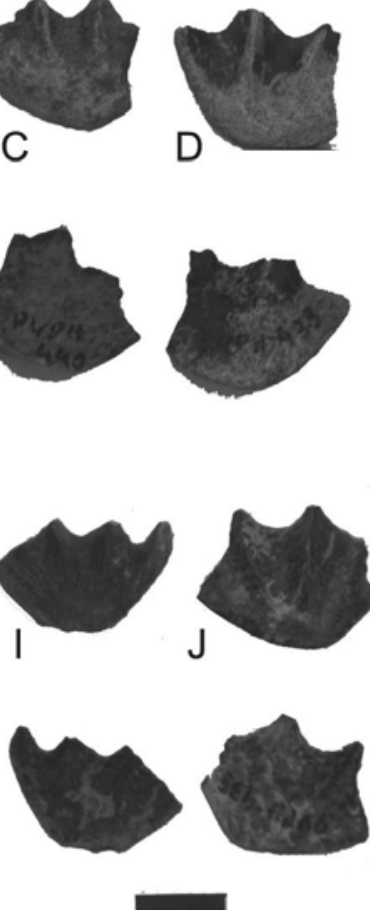
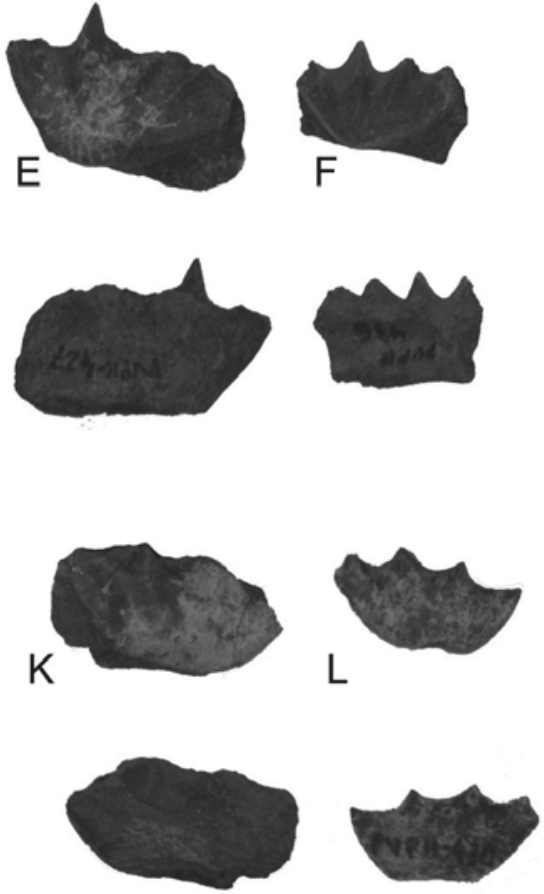

Fig. 5. Ptychoceratodontidae indet., A (MCF-PVPH- 439), B, C (MCF-PVPH-440), D (MCF-PVPH-453), E (MCFPVPH-427, upper), F (MCF-PVPH-436, upper), G (MCF-PVPH-431), H, I, J (MCF-PVPH-435, upper), K, L (MCFPVPH-430, lower).

1997). †Metaceratodus tooth plates differ mainly because in TMetaceratodus the first ridge crest on lower tooth plates is subequal to the lingual margin, whereas in remaining Neoceratodontidae it is much shorter.

tMetaceratodus is present from the Lower Cretaceous to the Pliocene of Australia (see Kemp, 1997). Here we refer the Argentinian material to TMetaceratodus (as previously proposed by Kemp, 1997) on the basis of the following combination of characters: robust ridge crests that originate medially, more than four ridge crests on lower tooth plates, first crest of lower tooth plates acute, occlusal pits wide and deep. Additionaly, ridge crests are more acute in †Metaceratodus than in †Ceratodus. Whereas in Ceratodus the angles between crests are close to straight $\left(90^{\circ}\right)$, in Metaceratodus they are acute $\left(60-70^{\circ}\right)$. The Argentinian material could be referred to the Cretaceous species $M$. wollastoni because the tooth plates are broader, stouter and have wider ridge crests than other species of the genus (i.e. M. elliotti; M. palmeri; M. bonei), and lacks the typical lingual keel. Additionaly, it shows the occlusal pits distributed in furrows and around the tooth plate (Kemp, 1997).
?Lepidosirenidae (MPCN-PV 1-6) (Fig. 3 FH). A fragmentary dipnoan tooth plate was collected from the Anacleto Formation at Río Ne-gro Province. It preserves only the anterior two ridges. The anteroposteriorly flattened ridges end in vertical transverse crests that follow a perpendicular plane respect to the skull. This material belongs to a different kind of dipnoan, probably a lepidosirenid.

\section{DISCUSSION}

\section{On the systematic value of tooth plates}

From 1899 to 1996, a single tooth plate represented the ceratodontiform record in Argen-tina from the Coniacian (Ameghino, 1899) and other fragments from the Campanian- Maas-trichtian (Wichmann, 1924; 1927; Cione, 1987). In years to follow, our understanding of the stratigraphic record has greatly increased and today we have information on a substantial por-tion of the Late Cretaceous (Fig. 1b). The record of lungfishes is still restricted to findings from the Cenomanian of the Candeleros (Apesteguía et al. 2001) and the Cerro Lisandro Formations (Apesteguía et al., 2001; Coria et al., 1996 con- 
signed there as Huincul Formation), Late Turonian of the Portezuelo Formation (herein), Coniacian of the Mata Amarilla Formation (Ameghino, 1899; Goin et al., 2002), Early Campanian of the Anacleto Formation (herein), and several units of the Late Campanian to Maastrichtian equivalent to the Allen Formation (Wichmann, 1924, 1927; Cione, 1987; Apesteguía

\& Cambiaso, 1999; González Riga, 1999).

Distinguishing supraspecific taxa of lungfishes based on isolated tooth plates is difficult (Kemp \& Molnar, 1981). In fact, Kirkland (1988) states that dipnoan taxa cannot be defined by means of tooth plates and that the skull roof is essential for generic classification (Kirkland, 1988; Schultze, 1991). Intraspecific variation in tooth plate morphology (i.e. number of ridges, and the related presence or absence of a poste-rior heel) noted by Kemp and Molnar (1981) has been attributed to growth. Additionally, Churcher (1995) maintains that the formation of deep grooves with acute angles between the ridge crests and chewing movements in relation to a hard diet could induce the occlusal surface marks. However, as Campbell \& Barwick (1990) pointed out, tooth plates are directly correlated to skull and mandible morphology, and they together can be useful for indicating position within lineages.

Much of the available fossil material for ceratodontiforms consists of isolated tooth plates. Therefore, in order to optimize the knowledge on ceratodontiform phylogeny, our work supports the inclusion of characters present in tooth plates. Tooth plates from Los Alamitos and La Colonia Formations are available in abundance, allowing several tooth plates to be analyzed from a single locality in order to recognize the most consistent features. Ideally, more characters (i.e. cranial and post-cranial) would contribute more understanding to an analysis, but we and other researchers (Martin, 1982; Martin et al. 1999) consider tooth plates to offer an abundant source of information that should not be ignored.

\section{Biogeography}

In addition to obvious differences in size, mobility and routes of dispersion, ceratodontiform dipnoans have a similar regional and stratigraphical distribution to that of ttitanosauriform sauropods, which have a vast Jurassic and early Cretaceous record in North America through the Cenomanian (Bonaparte 1986). Ceratodontiforms and ttitanosauriforms were considered extinct at the early late Cretaceous of North America. However, they reappeared during the Maastrichtian before their final ex-tinction within Laurasia at the end of the
Mesozoic. The North American Maastrichtian dipnoans (Parris et al ., 2001) and titanosaurs (Gilmore, 1922), seem to prove a South American origin based on their continuous record from the Cenomanian through the Maastrichtian in Southern Continents.

With the exception of those found in the early Paleocene of Bolivia (Schultze, 1991), there is no record of ceratodontiforms in the South Ameri-can Tertiary. Pascual \& Bondesio (1976) proposed that the tceratodontid extinction in Patagonia likely resulted from an inability to migrate north to warmer regions when the climate changed. The authors also discuss a connection between Patagonia and Australia through Antarctica based on similarities between the Australian lungfish Neoceratodus forsteri and the Pata-gonian species †Ameghinoceratodus iheringi. Pascual \& Bondesio (1976) also noted the pres-ence of TMetaceratodus wollastoni and several species of TPtychoceratodus in both landmasses. Therefore, we do not reject the hypothesis of a connection between Patagonia and Australia even though we consider †Ameghinoceratodus and Neoceratodus to be distantly related taxa.

Members of †Ptychoceratodontinae, may have had a wide pre-Cretaceous distribution throughout greater Gondwana (Apesteguía, 2002) including India, Madagascar, Australia and possibly Antarctica, where they currently have not been recovered (Martin et al. 1999). The occurrence of ptychoceratodontines in South America begins by the Campanian-Maastrichtian transgression or perhaps earlier (Fig. 5d,f,h,l; Fig. $6)$. Thus, it is probable that the different spe-cies of tPtychoceratodus from the CampanianMaastrichtian of Patagonia represent a later invasion from India, Madagascar, or Australia (through Antarctica).

Most pre-Campanian Cretaceous dipnoans from Argentina represent both endemic South American lineages (e.g., tChaoceratodus; tAmeghinoceratodus) as well as relicts of widely distributed Jurassic ceratodontiforms (e.g., †Ceratodus sp.). We also see that Cretaceous postCampanian dipnoans are dominated by possibly immigrant forms (e.g. ptychoceratodontines, †Metaceratodus) and poorly represented endemic lineages (e.g. tAmeghinoce-ratodus). A similar faunal pattern has also been reported for other vertebrate groups (Bonaparte, 1986).

\section{Brief comments on phylogenetic relation- ships}

Cione (1987), based on Martin (1982), considers + Ptychoceratodus wichmanni to be the sister taxon to $P$. madagascarensis (=Fergana- 


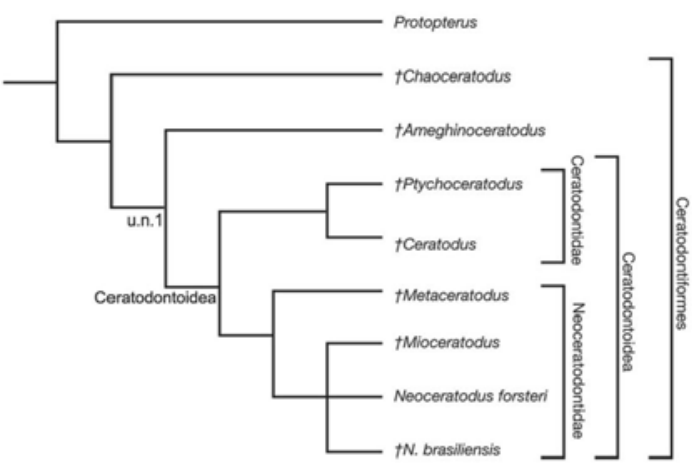

Fig. 6. Phylogenetic relationships of post-Triassic ceratodontiform dipnoans. Synapomophic characters detailed in the text. Clades Ceratodontinae and Ptychoceratodontinae are represented by genera Ceratodus and Ptychoceratodus respectively.

ceratodus; Martin et al., 1999) based on the presence of only four ridge crests in the tooth plates and the ontogenetic formation of a chewing surface. Although is not possible to follow developmental patterns of these extinct dipnoans, adult morphology is in agreement with this interpretation and thus we consider $P$. wichmanni and $P$. cionei as closely related to the $P$. madagascariensis species group (sensu Martin, 1982).

In this paper two new genera endemic to South America, tChaoceratodus and TAmeghinoceratodus, are considered basal to the «modern» clade of dipnoans, termed here as Ceratodontoidea, which includes the families †Ceratodontidae (†Ceratodontinae + †Ptychoceratodontinae) and Neoceratodontidae. The lat-ter family is composed by TMetaceratodus and tMioceratodus + Neoceratodus, which are characterized by a double prearticular sulcus and an increasing number of ridge crests per tooth plate. TMetaceratodus was considered by other authors as belonging either to the family †Ceratodontidae (Kemp \& Molnar, 1981; Kemp, 1997) or Ptychoceratodontidae (Martin, 1982). However, these authors based their hypothesis mainly on plesiomorphic traits (e.g. medial origin of ridge crests, upper tooth plates close or contiguous, upper symphysis oblong) that are widely distributed among dipnoans (e.g. Lepidosiren, Sagenodus; Fernández et al. 1973; Kemp, 1996).

Some authors (Kemp, 1998; Martin et al. 1999) proposed that both †Ceratodontidae and Ptychoceratodontidae were closely related clades. In this paper we agree with previous interpreta-tions and we include both groups as subfamilies within the single family $\uparrow$ Cerato-dontidae.

\section{Paleobiological considerations}

The rock units relevant to the «Lacustrine Senonian» are considered to be the first stages in the progressive flooding that formed the epeiric Kawas sea (Casamiquela, 1978). The ma-rine nature of these outcrops was mainly based on the presence of batoid fishes and plesiosaurs (e.g. Gasparini \& De la Fuente, 2000) . Further-more, the freshwater and terrestrial taxa also recovered in the same beds were considered as allochtonous additions although they lack any sign of transport.

The batoids present in several units of the «Lacustrine Senonian» (e.g. Los Alamitos and Loncoche Formations) actually pertain to the freshwater family Rhinobatidae (A. Forasiepi, pers. comm.; Gayet, 1992). Furthermore, the plesiosaur record does not necessarily imply marine sediments, as they have occasionally been found in freshwater sediments (R. Molnar, pers. comm. ). Additionally, several other faunal remains indicating a freshwater environment (e.g. Chelidae turtles, freshwater gatropods; Gasparini \& De la Fuente, 2000; A. Forasiepi, pers. comm.) have been recovered.

The ceratodontiforms from the «Lacustrine Senonian» appear to be common in the sediments prior to the marine transgression and Casa-miquela (1978) proposed that they were tolerant to brackish waters, in contrast with the strict freshwater living forms. Schultze (1991) proposed that extinct ceratodontiforms could be good swimmers and that they could undertake exten-sive sea voyages, which may explain their wide distribution in the Late Cretaceous. However, dipnoans disappeared abruptly during the first stage of the marine Turonian transgression of the Western sea in North America (Eaton \& Kirkland, 1999). Just as in Patagonia, dipnoans disappeared from the record when the Kawas sea flooded the continent, as evidenced by the faunal content of the clearly marine Upper section of the Los Alamitos Formation (and equivalents; Andreis, 1987). The freshwater environments inhabited by extant dipnoans, plus the fluvial pre-Campanian sediments of the Cretaceous South American ceratodontiforms, supports the conclu-sion that the «Lacustrine Senonian» forms inhabited freshwater environments.

\section{ACKNOWLEDGEMENTS}

We would like to thank J. González and G. Lío for support in the field and drawings, to R. Rogers and K. C. Rogers for information about the taphonomic model of the 'Lacustrine Se- 
nonian' and for helping us with photographic material. F. E. Novas and J. F. Bonaparte provided us with ceratodontiform materials from Pata-gonia. We also thank W. E. Bemis, A. Cione, and A. Forasiepi for their comments on the manu-script.

\section{BIBLIOGRAPHY}

Agassiz, L. 1838. Recherches sur les poisson fossils. 3: 1-390.

Ameghino, C. 1916. Sobre tCeratodus iheringi de la Formación Guaranítica de la Patagonia. Physis 2: 216.

Ameghino, F. 1899. Sinopsis geológico-paleontológica de la Argentina. Segundo Censo Nacional de la República Argentina; Supl. (adiciones y correcciones): 1-13.

- 1906. Les formations sédimentaires du Crétecé supérieur et du Teriaire de Patagonie. Anales del Museo Nacional, Buenos Aires. 3: 1-564.

Andreis, R. R. 1987. The late Cretaceous fauna of Los Alamitos, Patagonia, Argentina. Part I. Strati-graphy and paleoenvironment. Revista del Museo Argentino de Ciencias Naturales, Serie Paleontología, 3: 103-110.

Apesteguía, S. 2002. Greater Gondwana and the kawas sea coastal tetrapod fauna (CampanianMaas-trichtian). Boletim do $6^{\circ}$ Simpósio sobre 0 Cretáceo do Brasil / $2^{\circ}$ Simposio sobre el Cretácico de América del Sur. Sao Pedro, Brasil: 143-147.

Apesteguía, S. \& A. V. Cambiaso. 1999. Registro de hadrosaurios en la Formación Paso del Sapo, del Campaniano-Maastrichtiano de Chubut, su importancia bioestratigráfica y sus posibilidades de correlación con unidades contemporáneas. Ameghiniana 36(4): 26R.

Apesteguía, S., S. de Valais, J. A. González, P. A. Gallina \& F. L. Agnolin. 2001. The tetrapod fauna of 'La Buitrera', new locality from the basal Late Cretaceous of North Patagonia, Argentina. Journal of Vertebrate Palaeontology 21: 29A.

Berg, L. S. 1940. Classification of fishes, both recent and fossil. Travaux de l'Institut de Zoologie, Academie des Sciences de L'URSS, 5, 85-517.

Bertels, A. 1969. Estratigrafía del límite CretácicoTerciario en Patagonia septentrional. Revista de la Asociación Geológica Argentina 24: 41-54.

Bonaparte, J. F. 1986. History of the terrestrial Cretaceous vertebrates of Gondwana. IV Congreso Argentino de Paleontología y Bioestratigrafía, Actas 2: 63-95.

Bonaparte, J. F., M. R. Franchi, J. E. Powell \& E. G. Sepúlveda. 1984. La Formación Los Alamitos (Campaniano-Maastrichtiano) del sudeste del Río Negro, con descripción de Kritosaurus australis n.sp. (Hadrosauridae) . Significado paleogeográfico de los vertebrados. Revista de la Asociación Geológica Argentina 39: 284-299.

Campbell, K. S. W. \& R. E. Barwick. 1990. Paleozoic Dipnoan Phylogeny: Functional complexes and evolution without parsimony. Paleobiology 16: 143169.

Casamiquela, R. M. 1978. La Zona Litoral de la Transgresión Maastrichtense en el Norte de la Patagonia. Aspectos ecológicos. Ameghiniana 15: 137-147.

Chapman, A. 1914. On a new species of Ceratodus from the Upper Triassic of Western Texas. Occasional papers of the Museum of Zoology, University of Michigan 1-2.

Churcher, C. S. 1995. Giant Cretaceous lungfish Neoceratodus tuberculatus from a deltaic environment in the quseir (=Baris) Formation of Kharga Oasis, western desert of Egypt. Journal of Vertebrate Paleontology 15: 845-849.

Churcher, C. S. \& G. de Iuliis. 2001. A new species of Protopterus and a revision of Ceratodus humei (Dipnoi: Ceratodontiformes) from the Late Cretaceous Mut Formation of eastern Dakhleh Oasis, western desert of Egypt. Palaeontology 44(2): 305323.

Cione, A. 1987. The late Cretaceous fauna of Los Alamitos, Patagonia, Argentina. Part II. The Fishes. Revista del Museo Argentino de Ciencias Naturales, Serie Paleontología 3: 111-120.

Coria, R. A., G. Cladera \& L. Salgado. 1996. Sobre una nueva localidad fosilífera en la Formación Río Limay, Cretácico Superior temprano, en la localidad de Cerro Bayo Mesa, Provincia de Neuquén. Ameghiniana 33(4): 463.

Eaton, J. \& J. Kirkland. 1999. A preliminary assessment of diversity patterns of nonmarine Verte-brates in the Cretaceous Western Interior of North America. Abstracts VII International Symposium on Mesozoic Terrestrial Ecosystems, Buenos Aires, Argentina: 85.

Fernández, J., R. Pascual \& P. Bondesio. 1973. Restos de Lepidosiren paradoxa (Osteichthyes, Dipnoi) de la Formation Lumbrera (Eógeno, Eoceno?) de Jujuy. Consideraciones estratigráficas, paleoecológicas y paleogeográficas. Ameghiniana 10: 152172.

Gasparini, Z. \& M. de La Fuente. 2000. Tortugas y Plesiosaurios de la Formación La Colonia (Cretácico superior) de Patagonia, Argentina. Revista Espa-ñola de Paleontología 15(1): 23-35.

Gayet, M. 1992. «Holostean» and teleostean fishes of Bolivia. In: R. Suarez-Soruco, (ed.), Fósiles y Facies de Bolivia. Vol. I Vertebrados. Revista Técnica de YPFB 12: 441-448.

Gayet, M. \& P. M. Brito. 1989. Ichtyofaune Nouvelle de Cretacé Superieur du Groupe Baurú (Etats de Sao Paulo et Minas Gerais, Bresil). Geobios 22: 841847.

Gill, T. 1872. Arrangement of the families of fishes, or classes Pisces, Marsipobranchii and Leptocardii. Smithsonian Miscellaneous Collections, 247, 1-49.

Gilmore, C. W. 1922. A new sauropod dinosaur from the Ojo Alamo Formation of New Mexico. Smithsonian Miscellaneous Collections 72: 1-9.

Goin, F. J., D. G. Poiré, M. S. de La Fuente, A. L. Cione, O. Ferrer, N. D. Canessa, A. Carlini, J. Ferigolo, A. 
M. Ribeiro, M. S. Sales Viana, R. Pascual, M. Reguero, M. G. Vucetich \& S. Marensi. 2002. Paleontología y Geología de los sedimentos del Cretácico Superior aflorantes al sur del río Shehuen (Mata Amarilla, Provincia de Santa Cruz, Argentina). Actas del XV Congreso Geológico Argentino, Calafate, p. 37

Goloboff, P. 1993. NONA, computer program and software. Published by the author, Tucumán, Argentina.

González Riga, B. 1999. Hallazgo de vertebrados fósiles de la Formacion Loncoche, Cretácico Superior de la Provincia de Mendoza, Argentina. Ameghiniana 36(4): 401-410.

Jaekel, E. 1926. Zur Morphogenie der Gebisse und Zahne. Vierteljahrsschrift Zahnheilkunde, Berlin: 217-242.

Kemp, A. 1996. Sagenodus (Proceratodus) carlinvillensis (Romer and Smith 1934), (Osteichthyes: Dipnoi), short ridge anomaly and classification of dipnoans. Journal of Vertebrate Paleontology 16(1): 16-19.

- 1997. Four species of TMetaceratodus (Osteichthyes: Dipnoi, Family †Ceratodontidae) from Australian Mesozoic and Cenozoic deposits. Journal of Vertebrate Paleontology 17: 26-33.

- 1998 . Skull structure in Post-Paleozoic Lungfish. Journal of Vertebrate Paleontology 18: 43-63.

- 2001. Petrodentine in derived dipnoan tooth plates. Journal of Vertebrate Paleontology 21(3): 422-437.

Kemp, A. \& R. Molnar. 1981. Neoceratodus forsteri from the Lower Cretaceous of New South Wales, Australia. Journal of Paleontology 55: 211-217.

Kirkland, J. I. 1987. Upper Jurassic and Cretaceous lungfish tooth plates from the Western Interior, the last dipnoan faunas of North America. Hunteria 2: 116.

- $\quad$ 1988. Morrison Fishes. Modern Geology 22: 503533.

Krefft, G. 1870. Description of a giant amphibian al-lied to the genus Lepidosiren, from the Wide Bay District, Queensland. Proceedings of the Zoologi-cal Society of London 1870:221-224.

Martin, M. 1981. Les dipneustes mésozoiques malgaches, leurs affinités et leur intéret paléogéographiques. Bulletin de la Société Géologique de France 23: 579-585.

- 1982. Nouvelles donneés sur la phylogénie et la systématique des Dipneustes postpaléozoiques, conséquences stratigraphiques et paléogeographiques. Geobios, Mémoires spéciales 6: 53-64.

Martin, M., L. Barbieri \& G. Cuny. 1999. The Madagascan Mesozoic Ptychoceratodontids (Dipnoi).
Systematic relationships and Paleobiogeographical significance. Oryctos 2: 3-16.

Miles R. S. 1977. Dipnoan (lungfish) skulls and the relationships of the group; a study based on the species from the Devonian of Australia. Zoological Journal of the Linnean Society of London 61 (1-3): 1-328.

Müller, J. 1845. Mémoire sur les ganoides et sur la classification naturelle des Poissons: Annales des Sciences Naturelles 4: 5-53.

Novas, F. E. 1997. Anatomy of Patagonykus puertai (Theropoda, Avialae, Alvarezsauridae) from the Late Cretaceous of Patagonia. Journal of Vertebrate Paleontology 17: 137-166.

Ostrom, J. H. 1970. Stratigraphy and Paleontology of the Cloverly Formation (Lower Cretaceous) of the Big-horn Basin Area, Wyoming and Montana. Bulletin of the Peabody Museum of Natural History, 234 p.

Parris, D. C., B. S. Grandstaff, W. B. Gallagher. 2004. A lungfish (Dipnoan) from the Upper Cretaceous of New Jersey. The Mosasaur (vol 7): 65-68.

Pascual, R. \& P. Bondesio. 1976. Notas sobre vertebrados de la frontera Cretácico-Terciaria. III: †Ceratodontidae (Peces, Osteichthyes, Dipnoi) de la Formation Coli Toro y de otras unidades del Cretácico Tardío de Patagonia y sur de Mendoza. Sus implicancias paleobiogeográficas. Actas VI Congreso Argentino 1: 565-577.

Schultze, H. P. 1991. Lungfish from the El Molino (Late Cretaceous) and Santa Lucia Formations in Southcentral Bolivia. In: Suarez Soruco, R. (Ed.) Fósiles y Facies de Bolivia. Vol. I Vertebrados. Revista Técnica de YPFB 12: 441-448.

- 1992. Fossilium catalogus: Animalia. Pars 131. Dipnoi. Kugler Publications, Amsterdam. New York. $464 \mathrm{p}$.

Souza Cunha, F. \& C. Ferreira. 1980. Um Dipnoi na Formaçao Itapecurú (Cenomaniano) Maranhao, Brasil. Actas II Congreso Argentino de Paleontología y Bioestratigrafía y I Congreso Latinoamericano de Paleontología 1978. 2: 1-9.

Teller F. 1891. Ueber den Schädel eines fossilen Dipnoërs, Ceratodus Sturii nov. spec., aus den Schichten der oberen Trias der Nordalpen. Abhandlungen der Kaiserlich-königlichen geologischen Reichsanstalt, Wien 15 (3): 1-39.

Wichmann, R. 1924. Nuevas observaciones en la parte oriental del Neuquén y en el territorio del Río Negro. Dirección General de Minas, Geología e Hidrología 2: 1-32.

- 1927. Sobre las facies lacustre Senoniana de los estratos con dinosaurios y su fauna. Boletín de la Academia Nacional de Ciencias de la República Argentina 30: 383-405. 
Appendix 1. Description of characters used in phylogenetic analysis.

1. Calvarium bones distribution (Kemp 1998): Two bones in each of the medial and mediolateral series (0); Two unpaired in medial and one in mediolateral series (1); Three bones in medial and mediolateral series (2).

2. Posterior calvarium formed by (Kemp 1998): YZ, JLM, I, ABC (1); AB, IJ, YZ (2); I, AB (3).

3. Calvarium is emarginated (Kemp 1998): no (0); yes (1); only in the posterior edge (2).

4. JLM descending process (Kemp 1998): complex curved articular socket for twisted ascending pterygopaltine process what is covered laterally (0); simple peg-like fitting into the broad grooved pterygopalatine and exposed laterally (1); has a straight grooved process to articulate with a straight pterigopalatine process that is exposed laterally (2); absent (3).

5. KLM descending process (Kemp 1998): absent (0); present (1).

6. XK (Kemp 1998): absent (0); present (1).

7. Ornamented calvarium bones (Kemp 1998): absent (0); present (1).

8. Symphysis shape (Kemp 1998): superior oval, inferior linear (0); both oval (1); superior elliptic, inferior linear (2); superior oblong, inferior linear (3).

9. Upper tooth plate ridge crests No. $3(0) ; 4$ (1); 5(2); 6(3); 7(4).

10. Lower tooth plate ridge crests No. $3(0) ; 4-5(1) ;>6(2)$.

11. Punctation distribution: over most of surface (0); between ridge crests (1); absent (2).

12. Mesolingual keel: present (0); absent (1).

13. Upper tooth plate medial edge: straight (0); bent (1).

14. Lower tooth plate medial edge: straight (0); bent (1).

15. Ridge crests: long and sharp (0); short and sharp (1); short and rounded (2).

16. Dentine mantle (Kemp 1997, 1998): limited (0); broad (1).

17. Ridge crests origin (Kemp 1997, 1998): medial (0); anterior (1).

18. Upper tooth plates position (Kemp 1997, 1998): close or adjacent (0); separated (1), adjacent (2).

19. Occlusal perforations (Kemp 1997): absent (0); present (1).

20. Punctation distribution: with patern (0); without pattern (1).

21. ABC angle (Kirkland 1988): $>110^{\circ}(0) ;<110^{\circ}(1)$.

22. Tooth plates size: $1-2,5 \mathrm{~cm}(0) ;>2,5 \mathrm{~cm}(1)$.

23. $4^{\circ}$ ridge crest: absent (0); present and well developed (1); present and poorly developed (2).

24. Labial margin: stepped (0); non-stepped (1).

25. First ridge crest: similar to the second (0); $20 \%$ bigger (1); $20 \%$ smaller (2).

26. First ridge crest: shorter than lingual margin (0); longer than lingual margin (1); approximately equal to lingual margin (2).

27. Lingual margin: straight or slightly concave (0); convex (1).

28. Prearticular sulcus: single (0); double (1).

Appendix 2. Character codes used for the phylogenetic analysis.

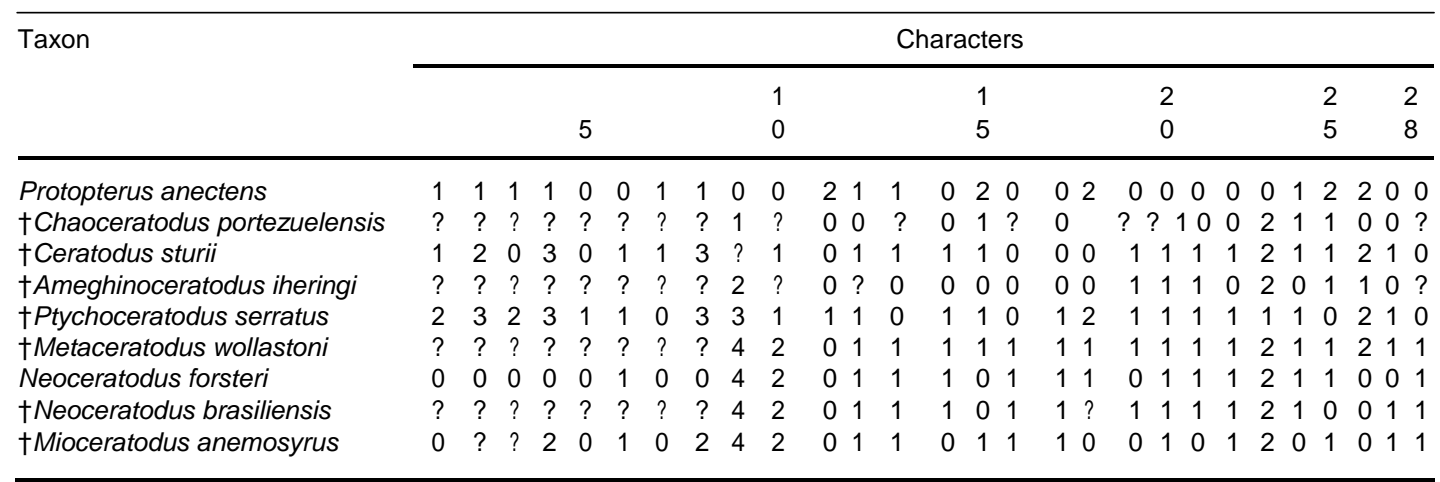


